\title{
Mobility, ecotoxicity, bioaccumulation and sources of trace elements in the bottom sediments of the Rożnów reservoir
}

\author{
Magdalena Szara-Bạk • Agnieszka Baran (D) Agnieszka Klimkowicz-Pawlas • \\ Joanna Tkaczewska $\cdot$ Barbara Wojtasik
}

Received: 14 January 2021/Accepted: 20 April 2021/Published online: 10 May 2021

(C) The Author(s) 2021

\begin{abstract}
The aim of the study was to use of geochemical, chemical, ecotoxicological and biological indicators for a comprehensive assessment of ecological risks related to the mobility, ecotoxicity and bioavailability of trace elements in the bottom sediment of the Rożnów reservoir. The study found three elements deserving attention in the sediments: cadmium, nickel and chromium. Cadmium proved to be the most mobile and bioavailable, although the total cadmium content and geochemical indicators did not reveal any risk to organisms. Geochemical indicators showed that the sediments are contaminated with nickel and chromium, but both elements had a low bioaccumulation factor. Fractional analysis also revealed relatively low mobility of $\mathrm{Cr}$ and $\mathrm{Ni}$ and a
\end{abstract}

M. Szara-Bạk · A. Baran ( $\square)$

Department of Agricultural and Environmental

Chemistry, University of Agriculture in Krakow, al.

Mickiewicza 21, Krakow, Poland

e-mail: Agnieszka.Baran@urk.edu.pl;

Agnieszka.Baran@ur.krakow.pl

M. Szara-Bąk

e-mail: Magdalena.Szara-Bak@urk.edu.pl

A. Klimkowicz-Pawlas

Department of Soil Science Erosion and Land Protection,

Institute of Soil Science and Plant Cultivation - State

Research Institute, Czartoryskich 8, 24-100, Puławy,

Poland

e-mail: agnes@iung.pulawy.pl higher potential risk of bioavailability for nickel. Most of the tested sediment samples had low toxicity in relation to the tested organisms. For $\mathrm{H}$. incongruens, $11 \%$ of the samples were non-toxic, $50 \%$ of the samples had low toxicity, and 39\% of the samples were toxic. For A. fischeri, no toxicity was found in $7 \%$ of the samples, low toxicity in $76 \%$ of the samples and toxicity in $17 \%$ of the sediment samples. The As, $\mathrm{Cd}, \mathrm{Cu}$ content in the $\mathrm{F} 1$ fraction correlated significantly positively with the content of these metals in mussel tissues. Both biotesting and chemical analysis can reveal a potential risk to aquatic organisms. For a real assessment of the ecological risks associated with trace elements, it is necessary to use bioindicators taken from the environment and exposed to trace elements in situ.

\footnotetext{
J. Tkaczewska

Department of Animal Product Processing, University of Agriculture in Krakow, Krakow, Poland

e-mail: joanna.tkaczewska@urk.edu.pl

B. Wojtasik

Department of Genetics and Biosystematics, University of Gdańsk, Gdańsk, Poland

e-mail: barbara.wojtasik@ug.edu.pl
} 
Keywords Trace elements - Fractions - Risk assessment · Mussels · Biotests · Bottom sediments

\section{Introduction}

Contamination with trace elements is the result of natural processes in the environment (e.g., weathering of rocks) as well as anthropogenic activity (Sarkar et al., 2014). The mobility and bioavailability of trace elements depend on the chemical form in which they occur in the environment. The most mobile is elements of anthropogenic origin in ionic and carbonate form. In turn, elements bound to silicates and primary minerals are characterized by limited mobility (Klink et al., 2019; Morillo, 2008). The analysis of total trace elements does not provide sufficient information to determine the risks associated with mobility and potential bioavailability, and therefore, methods allowing to determine individual metal fractions are used (McCready et al., 2010). The BCR sequential extraction procedure is the most common method here (Gleyzes et al., 2002; Nieto et al., 2007; Rosado et al., 2016) and involves increasing the extraction power from weak acids through reducers and oxidizers to strong mineral acids in order to dissolve successive trace element fractions (Bacon \& Davidsion 2008; Sarkar et al., 2014). Sequential chemical extraction by the modified BCR method allows to extract four fractions of trace elements: F1-exchangeable, easily soluble in acidic environment, characterized by the most unstable binding with sediments and therefore the most potentially available; F2-reducible, bound to $\mathrm{Fe}$ and $\mathrm{Mn}$ oxides, available when the oxygen conditions change; F3-oxidizable, bound to organic matter and sulfides, released under oxidative conditions; F4-residual, elements permanently bound to minerals, unavailable fraction (BCR, 2001; Sarkar et al., 2014; Baran et al., 2019a). However, it should be emphasized that the knowledge of the total metal content and fractions obtained through chemical analyses only allows for the assessment of potential hazards associated with trace elements in bottom sediments. A useful tool for the actual assessment of the risk related to the presence of trace elements in the bottom sediment, i.e., their bioavailability, ecotoxicity, is biological methods including biotests and bioindicators (Apitz, 2011; Hise et al., 2020). Biotests allow for the assessment of toxicity associated with the presence of contaminants in bottom sediments, while bioindicators enable the assessment of the level of bioavailability and bioaccumulation of a given compound (Apitz, 2011; Shirneshan et al., 2013; Vignati et al., 2019; Hise et al., 2020). In the case of aquatic ecosystems, bottom sediments are the main sorbents of contaminants whose concentrations in them reach much higher values than in water (Ashokkumar et al., 2009; Rosado et al., 2016). A change in environmental conditions, such as $\mathrm{pH}$ or redox potential, can lead to the release of elemental contaminants from sediments into the water (Horsfall \& Spiff, 2002; Morillo et al., 2008; Zoumis et al., 2001). This may have an adverse effect on benthic organisms due to their exposure to contaminants and ability to accumulate the bioavailable fraction of trace elements (Apitz, 2011). Therefore, benthic invertebrates are an important factor in the assessment of bioaccumulation and a link in the transport of contaminants up the trophic chain (Birch \& Apostolatos, 2013; Burgos \& Rainbow, 2001; Morillo et al., 2008). From all benthic organisms, mussels seem to be a good biological indicator of the mobility and bioavailability of trace elements in aquatic ecosystems, as they are filter feeders and live a sedentary lifestyle (Heroika et al., 2018; Klink et al., 2019; Honda \& Suzuki, 2020). Biotests are ecotoxicological methods which can be used to assess the potential biological response in environmental samples (Kuczyńska et al., 2005). An important factor in the use of biotests is the selection of an appropriate battery of test organisms. It is important that organisms belong to different taxonomic groups and represent different links in the trophic chain (Szara et al., 2020a, 2020b). According to current data, sediment chemical analyses should be complemented by ecotoxicological studies, as the large number of potentially toxic compounds in sediments makes chemical assessment time-consuming, costly and often impossible. In addition, neither bioavailability nor interaction between substances can be investigated by chemical methods (Wadhia \& Thompson, 2007; Baran \& Tarnawski, 2015; Cooman et al., 2015; Hise et al., 2020).

The aim of the study was to examine whether the application of geochemical, chemical (fractionation) and biological (biotests, bioindicators) indicators will allow for a comprehensive assessment of ecological risks related to the mobility, ecotoxicity and 
bioavailability of trace elements, as well as to indicate their origin (sources) in the bottom sediment of the Rożnów reservoir.

\section{Material and methods}

Sample collection

The bottom sediments were collected from the Rożnów reservoir which is located on the Dunajec River in Małopolskie Province, southern Poland. The studies of Tarnawski et al. (2017), Baran et al. (2019b) and Szara et al. (2020a, 2020b) provide more details on the Rożnów reservoir and the place where it is located. The bottom sediments were sampled at 46 points in three zones: inlet zone (10 samples), middle zone (22 samples) and outlet zone in the immediate vicinity of the dam (14 samples). The top layer of bottom sediments $(0-15 \mathrm{~cm})$ was collected with the use of the Ekman sampler (Szara et al., 2020a). The samples, under laboratory conditions, were air-dried at room temperature, homogenized, 2-mm sieved and put into polyethylene containers. The Anodonta anatina mussels were sampled from the Rożnów reservoir as follows: 7 individuals from the inlet zone, 2 individuals from the middle zone and 2 individuals from the outlet zone. The mussels were transferred to the laboratory in an ice cool box immediately after collection. To remove gut content, the water in which mussels were kept for $24 \mathrm{~h}$ was filtered and the conditions in the container were identical to those in the natural environment. The samples were lyophilized and homogenized in a mortar.

Chemical analysis

A four-step sequential chemical extraction scheme modified by BCR method was used for the quantitative determination of trace elements (As, Cd, $\mathrm{Cr}, \mathrm{Cu}, \mathrm{Ni}, \mathrm{Pb}, \mathrm{Zn}$ ) in individual fractions of bottom sediments (BCR 2001, Baran et al., 2019a). The determination revealed the following four element fractions: exchangeable fraction (F1 - ion exchange and carbonate, $\mathrm{CH}_{3} \mathrm{COOH}$ with a concentration of $0.11 \mathrm{~mol} \bullet \mathrm{dm}^{-3}$ and $\left.\mathrm{pH}=2\right)$; reducible fraction related to hydrated $\mathrm{Fe}$ oxides and $\mathrm{Mn}$ oxides (F2 reduction, extractable with $\mathrm{NH}_{2} \mathrm{OHHCl}$ with a concentration of $0.5 \mathrm{~mol} \bullet \mathrm{dm}^{-3}$ and $\mathrm{pH}=1.5$ ); oxidizable fraction related to organic matter (F3 - oxidation, extractable with hot $30 \% \mathrm{H}_{2} \mathrm{O}_{2}$ and further the mineralization products re-extracted with $\mathrm{CH}_{3} \mathrm{COONH}_{4}$ with a concentration of $0.5 \mathrm{~mol} \bullet \mathrm{dm}^{-3}$ and $\mathrm{pH}=2$ ); and residual fraction, i.e., elements bound to minerals (F4 hot digested in a mixture of $\mathrm{HNO}_{3}$ and $\mathrm{HClO}_{3}$ acids (3:2) v/v) (Baran et al., 2019a). The solutions of all fractions were centrifuged and filtered. The residues of all fractions were washed with distilled water and subjected to another centrifugation. The mussels were digested in a microwave (AntonPaar Multiwave 3000 microwave system) in a mixture of $\mathrm{HNO}_{3}$ and $\mathrm{HCl}(6: 1$ $\mathrm{v} / \mathrm{v}$ ) acids (suprapure, MERCK) to assess the trace element concentrations in them.

The element concentration in mussels and bottom sediments was determined with the use of an inductively coupled plasma optical emission spectrophotometer-Perkin Elmer ICP-OES Optima 7300 DV. The analytical method was assessed using the reference material BCR-701 (trace element fraction in sediments) and ERM - CE278k (trace elements in mussels). The results showed that the percentage of recovery was in the range between $79 \% \mathrm{Cr}$ and $124 \%$ $\mathrm{Pb}$ (fractionation) as well as between $79 \%$ As and $96 \%$ $\mathrm{Zn}$ (total in mussels).

\section{Ecotoxicological analysis}

Two biotests: Ostracodtoxkit and Microtox were used to evaluate the ecotoxicity of the bottom sediments (Baran et al., 2016; Szara et al., 2020b). The endpoint in the test was the inhibition of Aliivibrio fischeri luminescence. The Microtox biotest involved the measurement of the inhibition of bacterial luminescence after $15 \mathrm{~min}$ of samples exposure. A standard test procedure was used for sediment elutriate: $81.9 \%$ screening test. The analysis of changes in luminescence was performed using a Microtox M500 Analyzer (Microbics Corporation, 1992). The mortality and growth inhibition of the Heterocypris incongruens crustacean after a 6-day contact with the sediment was measured with the use of the Ostracodtoxkit biotest (Ostracodtoxkit, 2001; Cooman et al., 2015).

Assessment of potential ecological risks

\section{Chemical and geochemical indicators}

The potential bioavailability factor (PBF) and the RAC (Risk Assessment Code) classification were 
applied to assess hazards related to the potential mobility of heavy metals in the bottom sediments (AlMur, 2020; Bielicka-Giełdoń et al., 2013; Klink et al., 2019; Singh et al., 2005). The RAC classification of metals bound to fraction I is as follows (in F1 [\%]: $<1$ no risk; 1-10 low risk; 11-30 medium risk; 31-50 high risk; $50>$ very high risk) (Baran \& Tarnawski, 2015; Singh et al., 2005). The PBF was calculated as the ratio of the potential mobile fraction (PMF $\left.\sum F 1-F 3\right)$ of elements to the total element content (BielickaGiełdoń et al., 2013). The residual fraction (F4) was less mobile that the PMF $\sum F 1-F 3$ of elements (Aguilar-Hinojosa et al., 2016). The fraction 4 is related to the structure of minerals, and trace elements bound to it are stable and have no effect on water or organisms (Martinez-Santos et al., 2015; Baran et al., 2019a). The level of contamination and potential ecological risks related to trace elements in sediments were analyzed using single-element (Geoaccumulation Index, Contamination Factor, Potential Ecological Risk Factor) and multi-element (Pollution Load Index, Potential Ecological Risk Index) geochemical indicators (Table 1) (Kulbat \& Sokołowska, 2019; Tytła \& Kostecki, 2019). The geochemical background values by Bojakowska (2001): As $-5 \mathrm{mg}$; Cd$0.5 \mathrm{mg}$; $\mathrm{Cr}$ and $\mathrm{Ni}-5.0 \mathrm{mg} ; \mathrm{Cu}-6 \mathrm{mg} ; \mathrm{Pb}-10 \mathrm{mg}$; $\mathrm{Zn}-48 \mathrm{mg} \bullet \mathrm{kg}^{-1}$ were adopted for calculations.

\section{Bioaccumulation factor and ecotoxicity assessment}

The risk of accumulating trace elements from the sediments by the mussels was assessed by calculating the biota-sediment accumulation factor (BASF):

$B A S F=\frac{C m}{C s}$

where $\mathrm{Cm}$-concentration of each metal in the mussels; Cs-concentration of each metal in the bottom sediments.

The BASF values classify organisms as: macroconcentrators (BASF $>2)$, microconcentrators $(1<\mathrm{BASF}<2)$ and de-concentrators $(\mathrm{BASF}<1)$ (Szefer et al., 1999; Ziyaadini et al., 2017). The sediment toxicity was evaluated using the toxicity assessment method developed by Persoone et al. (2003): PE (percent toxic effect) $<20 \%$ no toxic effect; $20 \% \leq \mathrm{PE}<50 \%$ low toxic sample; $50 \% \leq$ $\mathrm{PE}<100 \%$ toxic sample; $\mathrm{PE}-100 \%$ very toxic sample.
Statistical analysis

The mean, standard deviation and the coefficient of variation $(\mathrm{CV} \%)$ were calculated. The principal component analysis (PCA) and Pearson's correlation matrix were applied to analyze the possible relationships between biological, chemical and ecotoxicological data. The Statistica 13 software was used for all statistical analyses.

\section{Results and discussion}

Fraction of trace elements in bottom sediments

The mobility and potential toxicity of trace elements for living organisms depend on their presence in bioavailable chemical forms (Baran et al., 2019a; Morillo et al., 2008). The fractional analysis made it possible to distinguish individual fractions of trace elements (F1-exchangeable, F2-reducible F3oxidizable, F4-residual) present in the tested sediment. The highest concentration of arsenic was found in the residual fraction (F4) $4.09 \mathrm{mg} / \mathrm{kg}$ (Table 2). For the reducible (F2) and oxidizable (F3) fractions, the average concentration of arsenic was $0.24 \mathrm{mg} / \mathrm{kg}$ and $0.89 \mathrm{mg} / \mathrm{kg}$, respectively. In the exchangeable fraction (F1), the average concentration of the element was very low $(0.003 \mathrm{mg} / \mathrm{kg})$. Cadmium was mainly bound to exchangeable and reducible fractions $(\mathrm{F} 1=0.14 \mathrm{mg} / \mathrm{kg}, \mathrm{F} 2=0.09 \mathrm{mg} / \mathrm{kg})$. In the oxidizable fraction (F3), the cadmium concentration was on average $0.02 \mathrm{mg} / \mathrm{kg}^{1}$. This element was not found in the residual fraction (F4). Chromium was found primarily in the $\mathrm{F} 4$ fraction $(58.96 \mathrm{mg} / \mathrm{kg}$ on average). In other fractions, the chromium content was lower, F3 $(4.06 \mathrm{mg} / \mathrm{kg}), \mathrm{F} 2(0.32 \mathrm{mg} / \mathrm{kg})$ and F1 $(0.18 \mathrm{mg} / \mathrm{kg})$. The distribution of copper, nickel and zinc concentrations in individual fractions was as follows: The highest concentrations were found in the residual fraction $(23.36 \mathrm{mg} / \mathrm{kg} \mathrm{Cu}, 21.44 \mathrm{mg} / \mathrm{kg} \mathrm{Ni}, 44.69 \mathrm{mg} /$ $\mathrm{kg} \mathrm{Zn}$ on average), followed by the oxidizable fraction (3.99 mg/kg Cu, $12.80 \mathrm{mg} / \mathrm{kg} \mathrm{Ni}, 12.76 \mathrm{mg} / \mathrm{kg} \mathrm{Zn} \mathrm{on}$ average $)$ and the lowest in exchangeable $(0.83 \mathrm{mg} / \mathrm{kg}$ $\mathrm{Cu}, 1.79 \mathrm{mg} / \mathrm{kg} \mathrm{Ni}, 7.26 \mathrm{mg} / \mathrm{kg} \mathrm{Zn}$ on average) and reducible $(0.78 \mathrm{mg} / \mathrm{kg} \mathrm{Cu}, 1.42 \mathrm{mg} / \mathrm{kg} \mathrm{Ni}, 5.22 \mathrm{mg} / \mathrm{kg}$ $\mathrm{Zn}$ on average) fractions. Lead was mainly bound to the residual fraction $(6.09 \mathrm{mg} / \mathrm{kg}$ on average). In other fractions, the lead concentration was on average 
Table 1 The criteria of contamination level of toxic elements in bottom sediment

\begin{tabular}{|c|c|c|c|}
\hline Indices* & Equation with description & Category & $\begin{array}{l}\text { Category with description and } \\
\text { abbreviations }\end{array}$ \\
\hline \multirow{7}{*}{$\begin{array}{l}\text { Geoaccumulation Index } \\
\text { (Igeo) of single element }\end{array}$} & \multirow{7}{*}{$\begin{array}{l}I_{\text {geo }}=\log _{2}\left(\frac{C_{n}}{1,5 B_{n}}\right) C_{n}-\text { measured } \\
\text { concentration of element in the } \\
\text { sediment sample, } B_{n}-\text { geochemical } \\
\text { background value in the Earth's crust }\end{array}$} & $I_{\text {geo }} \leq 0$ & Practically uncontaminated (PUC) \\
\hline & & $0<I_{\text {geo }} \leq 1$ & $\begin{array}{l}\text { Uncontaminated to moderately } \\
\text { contaminated (U-MC) }\end{array}$ \\
\hline & & $1<I_{\text {geo }} \leq 2$ & Moderately contaminated (MC) \\
\hline & & $2<I_{\text {geo }} \leq 3$ & $\begin{array}{l}\text { Moderately to heavily contaminated } \\
\text { (M-HC) }\end{array}$ \\
\hline & & $3<I_{\text {geo }} \leq 4$ & Heavily contaminated (HC) \\
\hline & & $4<I_{\text {geo }} \leq 5$ & $\begin{array}{l}\text { Heavily to Extremely contaminated } \\
\text { (H-EC) }\end{array}$ \\
\hline & & $5<I_{\text {geo }}$ & Extremely contaminated (EC) \\
\hline \multirow{4}{*}{$\begin{array}{l}\text { Contamination Factor } \\
\text { (CF) index of single } \\
\text { element (Hakanson } \\
1980)\end{array}$} & $\mathrm{CF}=\frac{C_{0-1}^{i}}{C_{n}^{i}}$ & $\mathrm{CF}<1$ & Low contamination (LC) \\
\hline & $\begin{array}{l}C_{0-1}^{i} \text {-mean content of elements from at } \\
\text { list five sampling sites, }\end{array}$ & $1<\mathrm{CF}<3$ & Moderate contamination (MC) \\
\hline & $\begin{array}{l}C_{n}^{i} \text {-concentration of elements in the } \\
\text { Earth's crust }\end{array}$ & $3<\mathrm{CF}<6$ & Considerable contamination (CC) \\
\hline & & $\mathrm{CF}>6$ & Very high contamination (VHC) \\
\hline \multirow{5}{*}{$\begin{array}{l}\text { Potential Ecological Risk } \\
\text { Factor }\left(E_{r}^{i}\right) \text { index of } \\
\text { single element } \\
\text { (Hakanson 1980) }\end{array}$} & $E_{r}^{i}=T_{r}^{i} \times C_{f}^{i}=T_{r}^{i} \times\left(C_{i} / C_{0}\right.$ & $E_{r}^{i}<40$ & Low risk (LR) \\
\hline & $\begin{array}{l}C_{f}^{i}-\text { contamination factor of the trace } \\
\text { elements, }\end{array}$ & $40<E_{r}^{i}<80$ & Moderate risk (MR) \\
\hline & $\begin{array}{l}C_{i}-\text { concentration of metal } \mathrm{i} \text { in bottom } \\
\text { sediment, }\end{array}$ & $80<E_{r}^{i}<160$ & Considerable risk (CR) \\
\hline & $\begin{array}{l}C_{0}-\text { background value of the metal in the } \\
\text { study area, }\end{array}$ & $160<E_{r}^{i}<320$ & High risk (HR) \\
\hline & $\begin{array}{l}T_{r}^{i}-\text { biological toxicity factor of an } \\
\text { individual element, which was } \\
\text { determined for } \mathrm{Zn}=1, \mathrm{Cr}=2, \\
\mathrm{Cu}=\mathrm{Pb}=\mathrm{Ni}=5, \mathrm{As}=10, \mathrm{Cd}=30 \\
\text { (Hakanson 1980; Baran et al. } 2016 \text { ) }\end{array}$ & $E_{r}^{i}>320$ & Very high (VHR) \\
\hline \multirow{6}{*}{$\begin{array}{l}\text { Pollution Load Index } \\
\text { (PLI) of multi-element }\end{array}$} & PLI $=\left(C_{\mathrm{f} 1} \times C_{f 2} \times \ldots \times C_{f n}\right)^{1 / n}$ & $0<\mathrm{PLI} \leq 1$ & Unpolluted (UP) \\
\hline & $\begin{array}{l}C_{\mathrm{f}}-\text { contamination factor for individual } \\
\text { metals: }\end{array}$ & $1<\mathrm{PLI} \leq 2$ & Moderately to unpolluted (MUP) \\
\hline & $C_{\mathrm{f}}=C_{\mathrm{i}} / C_{0}$ & $2<\mathrm{PLI} \leq 3$ & Moderately polluted (MP) \\
\hline & $\begin{array}{l}C_{\mathrm{i}} \text { - concentration of metal } i \text { in bottom } \\
\text { sediment, }\end{array}$ & $3<\mathrm{PLI} \leq 4$ & Moderately to highly polluted (MHP) \\
\hline & $\begin{array}{l}C_{0} \text { - background value of the metal in the } \\
\text { study area, }\end{array}$ & $4<\mathrm{PLI} \leq 5$ & Highly polluted (HP) \\
\hline & $n=$ number of metals & PLI $>5$ & Very highly polluted (VHP) \\
\hline \multirow{4}{*}{$\begin{array}{l}\text { Potential Ecological Risk } \\
\text { Index (PERI) of multi- } \\
\text { element (Hakanson } \\
\text { 1980) }\end{array}$} & \multirow{4}{*}{ PERI $=\sum_{\mathrm{i}=1}^{\mathrm{n}} \mathrm{E}_{\mathrm{r}}^{\mathrm{i}}$} & PERI $<150$ & Low risk (LR) \\
\hline & & $150<$ PERI $<300$ & Moderate risk (MR) \\
\hline & & $300<$ PERI $<600$ & Considerable risk (CR) \\
\hline & & PERI $>600$ & High risk (HR) \\
\hline
\end{tabular}

*Hakanson (1980), Kulbat and Sokołowska (2019), Tytła and Kostecki (2019) 
Table 2 Content of trace elements (mean \pm SD) in bottom sediments $(n=46)$ and mussels $(n=10)$

\begin{tabular}{|c|c|c|c|c|c|c|c|c|}
\hline \multirow{4}{*}{$\begin{array}{l}\text { Materials } \\
\text { Bottom } \\
\text { sediment }\end{array}$} & As & $\mathrm{Cd}$ & $\mathrm{Cr}$ & $\mathrm{Cu}$ & $\mathrm{Ni}$ & $\mathrm{Pb}$ & $\mathrm{Zn}$ & \\
\hline & \multicolumn{8}{|c|}{ Content of trace elements in different fractions $\mathrm{mg} / \mathrm{kg}$} \\
\hline & $\mathrm{F} 1$ & $0.003 \pm 0.01$ & $0.14 \pm 0.04$ & $0.18 \pm 0.05$ & $0.83 \pm 0.29$ & $1.79 \pm 0.51$ & $0.21 \pm 0.10$ & $7.26 \pm 3.74$ \\
\hline & $\mathrm{F} 2$ & $0.24 \pm 0.11$ & $0.09 \pm 0.21$ & $0.32 \pm 0.08$ & $0.78 \pm 0.62$ & $1.42 \pm 0.37$ & $2.79 \pm 0.76$ & $5.22 \pm 1.07$ \\
\hline & F3 & $0.89 \pm 0.19$ & $0.02 \pm 0.04$ & $4.06 \pm 1.44$ & $3.99 \pm 4.30$ & $12.80 \pm 5.26$ & $2.10 \pm 1.06$ & $12.76 \pm 5.22$ \\
\hline & $\mathrm{F} 4$ & $4.09 \pm 1.01$ & 0.00 & $58.96 \pm 11.82$ & $23.36 \pm 14.79$ & $21.44 \pm 7.67$ & $6.09 \pm 1.46$ & $44.69 \pm 11.93$ \\
\hline & Total* & $5.24 \pm 1.11$ & $0.26 \pm 0.13$ & $63.23 \pm 12.66$ & $28.65 \pm 18.81$ & $37.11 \pm 7.69$ & $11.15 \pm 1.95$ & $69.69 \pm 12.73$ \\
\hline & $\mathrm{PBF}$ & $0.23 \pm 0.07$ & $1.00 \pm 0.02$ & $0.07 \pm 0.02$ & $0.21 \pm 0.16$ & $2.56 \pm 1.00$ & $0.45 \pm 0.11$ & $0.37 \pm 0.11$ \\
\hline & Risk** & \multicolumn{7}{|l|}{$\%$ of samples } \\
\hline & No & 100 & 0 & 97 & 3 & 3 & 17 & 0 \\
\hline & Low & 0 & 4 & 3 & 91 & 89 & 80 & 67 \\
\hline & Medium & 0 & 3 & 0 & 5 & 8 & 3 & 26 \\
\hline & High & 0 & 17 & 0 & 0 & 0 & 0 & 7 \\
\hline & V. high & 0 & 75 & 0 & 0 & 0 & 0 & 0 \\
\hline \multirow[t]{5}{*}{ Mussels } & \multirow[t]{3}{*}{$\begin{array}{r}\text { Content } \\
\mathrm{mg} / \mathrm{kg}\end{array}$} & As & $\mathrm{Cd}$ & $\mathrm{Cr}$ & $\mathrm{Cu}$ & $\mathrm{Ni}$ & $\mathrm{Pb}$ & $\mathrm{Zn}$ \\
\hline & & $5.66 \pm 1.79$ & $0.68 \pm 0.51$ & $2.11 \pm 0.97$ & $6.80 \pm 3.21$ & $1.04 \pm 0.38$ & $0.73 \pm 0.28$ & $141.1 \pm 56.3$ \\
\hline & & $2.93-10.96$ & $0.15-1.82$ & $0.56-4.43$ & $3.47-16.25$ & $0.42-1.95$ & $0.20-1.27$ & $55.5-306$ \\
\hline & \multirow[t]{2}{*}{ BASF } & $1.08 \pm 0.34$ & $2.63 \pm 1.96$ & $0.03 \pm 0.02$ & $0.24 \pm 0.11$ & $0.03 \pm 0.01$ & $0.07 \pm 0.03$ & $2.02 \pm 0.81$ \\
\hline & & $0.56-2.04$ & $0.57-7.00$ & $0.01-0.07$ & $0.12-0.57$ & $0.01-0.05$ & $0.02-0.11$ & $0.80-4.40$ \\
\hline
\end{tabular}

*Szara et al. (2020a), *Elements in mobile fraction MF [\%]: < 1 no risk; 1-10 low risk; 11-30 medium risk; 31-50 high risk; $50>$ very high risk (Singh et al., 2005). $P B F$ potential bioavailability factor; BASF biota-sediment accumulation factor; values in italic mean the range from minimum to maximum

$0.21 \mathrm{mg} / \mathrm{kg}$ (F1), $2.79 \mathrm{mg} / \mathrm{kg}(\mathrm{F} 2), 2.10 \mathrm{mg} / \mathrm{kg}$ (F3). In summary, the trace element content in the tested sediment was found in the individual fractions in the following order: As and $\mathrm{Cr}$ : residual $(\mathrm{F} 4)>$ oxidizable $(\mathrm{F} 3)>$ reducible $(\mathrm{F} 2)>$ exchangeable $(\mathrm{F} 1)$; $\mathrm{Cd}$ : exchangeable $\quad(\mathrm{F} 1)>$ reducible $\quad(\mathrm{F} 2)>$ oxidizable $(\mathrm{F} 3)>$ residual $(\mathrm{F} 4)$; $\mathrm{Cu}, \mathrm{Ni}, \mathrm{Zn}$ : residual $(\mathrm{F} 4)>$ oxidizable $(\mathrm{F} 3)>$ exchangeable $(\mathrm{F} 1)>$ reducible $(\mathrm{F} 2)$; $\mathrm{Pb}$ : residual $(\mathrm{F} 4)>$ reducible $(\mathrm{F} 2)>$ oxidizable (F3) $>$ exchangeable (F1). The share of trace elements in individual fractions changed depending on the tested reservoir zone (Fig. 1). In the inlet, middle and outlet zones of the reservoir, the residual fraction (F4) dominated for all elements except for cadmium, representing 71-80\% As; 91-94\% Cr; 75-84\% Cu; $43-68 \% \mathrm{Ni} ; 42-62 \% \mathrm{~Pb}$; and $55-71 \% \mathrm{Zn}$, respectively. In the reservoir inlet zone, the share of elements in $\mathrm{F} 1$ was: $80 \% \mathrm{Cd} ; 17 \% \mathrm{Zn} ; 7 \% \mathrm{Ni} ; 4 \% \mathrm{~Pb} ; 2 \%$ $\mathrm{Cu} ;<1 \% \mathrm{Cr}$. No arsenic was found in the exchangeable fraction. Cadmium was only bound to the exchangeable fraction $(\mathrm{F} 1)$ and the reducible fraction (F2). In the reservoir middle zone, on average $<1 \%$ As and $\mathrm{Cr} ; 73 \% \mathrm{Cd} ; 1 \% \mathrm{Cu}, \mathrm{Pb} ; 5 \% \mathrm{Ni} ; 8 \% \mathrm{Zn}$ in the exchangeable fraction (F1) were found. In this zone, cadmium was also present only in exchangeable (F1) and reducible (F2) fractions. The percentage of elements in the F1 fraction in the reservoir outlet zone was as follows: $1 \% \mathrm{As}, \mathrm{Cr} ; 43 \% \mathrm{Cd} ; 1 \% \mathrm{Cu} ; 4 \%$ $\mathrm{Ni} ; 2 \% \mathrm{~Pb} ; 11 \% \mathrm{Zn}$.

Generally, trace elements in the exchangeable fraction (F1) are considered more mobile and bioavailable. Based on the RAC classification, which takes into account the presence of trace elements in the exchangeable fraction (F1), it was found (Table 2): no risk related to the release of arsenic (100\% of samples) and chromium ( $97 \%$ of samples) into the environment, low risk related to the release of copper $(91 \%$ of samples), nickel (89\% of samples), lead ( $80 \%$ of samples) and zinc (67\% of samples) and very high risk of cadmium release ( $75 \%$ of samples). The highest share of potential mobile fraction (PMF $\sum$ F1-F3) was found for $\mathrm{Cd}$ (92\%); $\mathrm{Ni}, \mathrm{Pb}(47 \%)$; $\mathrm{Zn} \mathrm{(39 \% );} \mathrm{As}$ (24\%), $\mathrm{Cu}(18 \%)$ and $\mathrm{Cr}(8 \%)$ of the mean total element content. The presence of trace elements in potential mobile forms (PMF $\sum F 1-F 3$ ) probably indicates their anthropogenic source, while in the 
fourth fraction (F4), elements of lithogenic origin are usually available (Baran et al., 2019a). It was observed in the study that the percentages of trace elements bound in the PMF (without $\mathrm{Cd}$ ) were from $1.2(\mathrm{Ni}, \mathrm{Pb}$ ) to $12(\mathrm{Cr})$ fold lower than those of the F4. This implies that $\mathrm{Cr}, \mathrm{Cu}, \mathrm{As}, \mathrm{Ni}, \mathrm{Pb}$ and $\mathrm{Zn}$ generally came from natural and anthropogenic inputs and $\mathrm{Cd}$ and form anthropogenic sources. The residual fraction (F4) of trace elements represented on average $76 \%$ As, $0 \%$ $\mathrm{Cd}, 93 \% \mathrm{Cr}, 80 \% \mathrm{Cu}, 54 \% \mathrm{Ni}, \mathrm{Pb}$ and $61 \% \mathrm{Zn}$ of their total content. The potential bioavailability factor (PBF) achieved the following mean values 2.56 $\mathrm{Ni}>1.00 \mathrm{Cd}>0.45 \mathrm{~Pb}>0.37 \mathrm{Zn}>0.23 \mathrm{As}>0.21$ $\mathrm{Cu}>0.07 \mathrm{Cr}$ (Table 2). The high PBF values for nickel and cadmium were probably due to their potential toxicity, as they are easily released into the aquatic environment, ingested by organisms and entered into the food chain in studied reservoir.

Other researchers found that the trace elements bound to the $\mathrm{F} 1$ fraction, in addition to being the most mobile and bioavailable, also provide information on the recent bottom sediment contamination (Klink et al., 2019). In our study, Cd had the highest percentage bound to the $\mathrm{F} 1$ fraction of all trace elements. The presence of a trace element in fractions F2 (reducible) or F3 (oxidizable) may be related to its emission from anthropogenic sources in an earlier period (Klink et al., 2019). Additionally, the mobility and bioavailability of elements in F2 and F3 are strongly dependent on physical and chemical factors (availability of oxygen, redox potential, $\mathrm{pH}$, microbial activity). In the present study, $\mathrm{Ni}, \mathrm{Zn}, \mathrm{Cu}, \mathrm{Pb}(\mathrm{F} 3)$ and
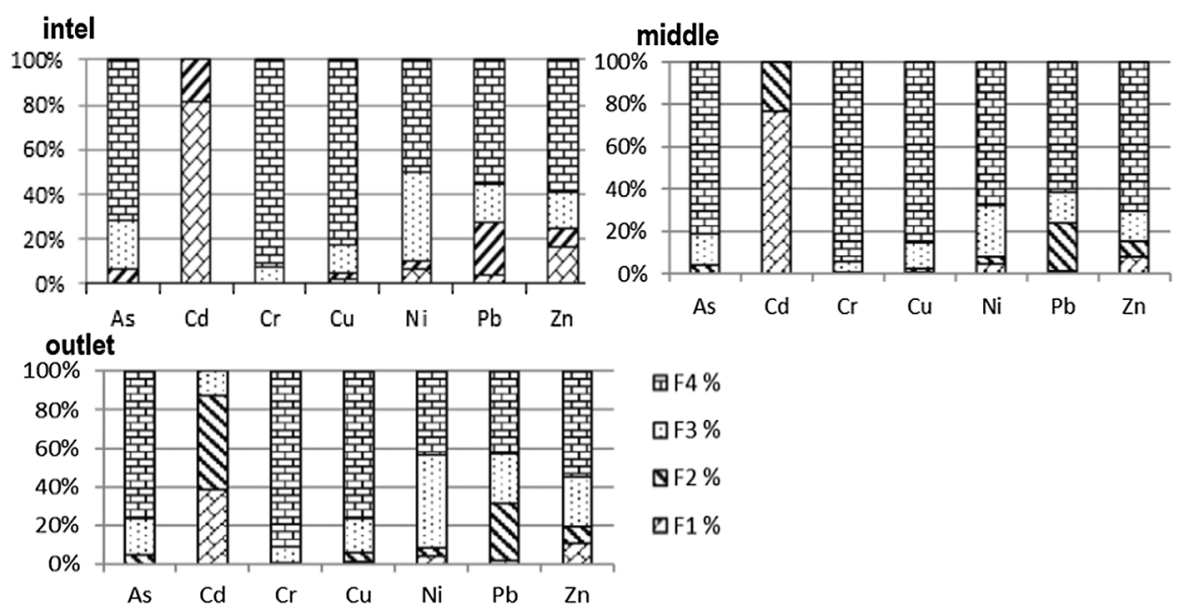

回 $4 \%$

口F3\%

$\triangle \mathrm{F} 2 \%$

DF1\%

Fig. 1 Fractional distribution and speciation of heavy metals in the bottom sediments 
decreased the binding of elements in the mobile fractions (F1) (Baran et al., 2019a).

Assessment of contamination level of trace elements in bottom sediments

Many authors consider that the key factor for using geochemical parameters is to find the difference between trace elements of anthropogenic origin and those from natural sources (Birch, 2017). The Geoaccumulation Index (Igeo) values showed that, depending on the tested element, the bottom sediments were practically uncontaminated ( $\mathrm{As}, \mathrm{Cd}, \mathrm{Pb}, \mathrm{Zn}$ ), moderately contaminated $(\mathrm{Cu})$, moderately to heavily contaminated (Ni), heavily contaminated (Cr) (Table 3). Igeo had the following order: $\mathrm{Cr}>\mathrm{Ni}>\mathrm{Cu}>\mathrm{Zn}>$ $\mathrm{Pb}>\mathrm{As}>\mathrm{Cd}$. The second tested single-element indicator was the Contamination Factor (CF) on the basis of which the elements formed the same series as in the case of Igeo: $\mathrm{Cr}>\mathrm{Ni}>\mathrm{Cu}>\mathrm{Zn}>\mathrm{Pb}>$ As $>\mathrm{Cd}$. The sediments were characterized by low contamination $(\mathrm{Cd})$, moderate contamination ( $\mathrm{As}, \mathrm{Pb}$, $\mathrm{Zn}$ ), considerable contamination $(\mathrm{Cu})$, and very high contamination $(\mathrm{Cr}, \mathrm{Ni})$. The Potential Ecological Risk Factor $\left(\mathrm{E}_{\mathrm{r}}^{\mathrm{i}}\right)$ showed that the bottom sediments were characterized by a low contamination risk related to the content of all trace elements $\left(\mathrm{E}_{\mathrm{r}}^{\mathrm{i}}\right.$ : $\mathrm{As}=10,44$; $\mathrm{Cd}=15,58 ; \mathrm{Cr}=25,23 ; \mathrm{Cu}=23,87 ; \mathrm{Ni}=37,11 ;$ $\mathrm{Pb}=5,58 ; \mathrm{Zn}=1,45)$. Another group of indicators were multi-element indicators, calculated for 7 tested elements. The Pollution Load Index (PLI) value for the studied sediment was 2.10 , which indicates moderate sediment contamination. The last analyzed indicator was the Potential Ecological Risk Index (PERI) whose value indicated a moderate risk $($ PERI $=119.23)($ Table 3$)$. In our previous studies on the analysis of core bottom sediment samples from the Rożnów reservoir, similar relationships were shown, i.e., $\mathrm{Cr}$ and $\mathrm{Ni}$ were found to be significant contaminants of the Rożnów reservoir bottom sediments (Baran et al., 2019b). Also in the study by Szara et al (2020a), using consensus-based sediment quality guideline (the TEC and PEC values), it was demonstrated that $2 \%$ of samples were above the PEC values for $\mathrm{Ni}$ and the TEC values were exceeded for $\mathrm{Ni}$ and $\mathrm{Cr}$ in $93 \%$ of samples. The mean PECq of trace elements was 0.26 , meaning that the total trace element content was likely to cause moderate potential toxicity to the biological communities in the bottom sediments (Szara et al., 2020a).

Bioconcentration of trace elements in mussels

The trace element concentration in the mussel tissues varies from 2.93 to $10.96 \mathrm{mg} \mathrm{As}, 0.15$ to $1.82 \mathrm{mg} \mathrm{Cd}$, 0.56 to $4.43 \mathrm{mg} \mathrm{Cr}, 3.47$ to $16.25 \mathrm{Cu}, 0.42$ to $1.95 \mathrm{mg}$ $\mathrm{Ni}, 0.20$ to $1.27 \mathrm{mg} \mathrm{Pb}$ and 55.5 to $306 \mathrm{mg} / \mathrm{kg} \mathrm{Zn}$ (Table 2). Our study results showed the following overall pattern of trace elements in the mussels: $\mathrm{Zn}>\mathrm{Cu}>\mathrm{As}>\mathrm{Cr}>\mathrm{Ni}>\mathrm{Pb}>\mathrm{Cd}$. The highest contents of arsenic $(6.55 \mathrm{mg} / \mathrm{kg})$, cadmium $(1.64 \mathrm{mg} / \mathrm{kg})$, chromium $(3.22 \mathrm{mg} / \mathrm{kg})$ and nickel $(1.09 \mathrm{mg} / \mathrm{kg})$ were determined in mussels collected in the outlet zone of the reservoir. Mussels from the inlet zone had the highest copper content $(7.59 \mathrm{mg} /$ $\mathrm{kg}$ ). In the case of lead, the mussels of each zone

Table 3 Assessment of sediment contamination level and potential ecological risk $(n=46)$

\begin{tabular}{|c|c|c|c|c|c|c|c|c|c|c|}
\hline Metal & Igeo** & & $\mathrm{CF}$ & & $E_{r}^{i}$ & & PLI & & PERI & \\
\hline As & -0.52 & PUC* & 1.04 & $\mathrm{MC}$ & 10.44 & LR & 2.10 & MP & 119.23 & LR \\
\hline $\mathrm{Cd}$ & -1.53 & PUC & 0.52 & $\mathrm{LC}$ & 15.58 & LR & & & & \\
\hline $\mathrm{Cr}$ & 3.07 & $\mathrm{HC}$ & 12.62 & VHC & 25.23 & LR & & & & \\
\hline $\mathrm{Cu}$ & 1.67 & $\mathrm{MC}$ & 4.77 & $\mathrm{CC}$ & 23.87 & LR & & & & \\
\hline $\mathrm{Ni}$ & 2.31 & M-HC & 7.42 & VHC & 37.11 & LR & & & & \\
\hline $\mathrm{Pb}$ & -0.43 & PUC & 1.12 & $\mathrm{MC}$ & 5.58 & LR & & & & \\
\hline $\mathrm{Zn}$ & -0.05 & PUC & 1.45 & $\mathrm{MC}$ & 1.45 & LR & & & & \\
\hline
\end{tabular}

*PUC Practically uncontaminated, $H C$ heavily contaminated, $M C$ moderately contaminated, $M$ - $H C$ moderately to heavily contaminated, $L C$ low contamination, $V H C$ very high contamination, $C C$ considerable contamination, $L R$ low risk, $M P$ moderately polluted, **Igeo Geoaccumulation Index, $C F$ Contamination Factor, $E_{\mathrm{r}}^{i}$ Potential Ecological Risk Factor, PLI Pollution Load Index, PERI Potential Ecological Risk Index 
contained similar levels of the element. In turn, the highest zinc contents were recorded for mussels collected in the reservoir middle zone. The BASF calculated for the mussels of the Rożnów reservoir ranged from $0.01(\mathrm{Cr})$ to $7.00(\mathrm{Cd})$ (Table 2). The highest mean values of BASF were found for $\mathrm{Cd}$ (2.63), followed by $\mathrm{Zn}(2.02)>$ As $(1.08)>\mathrm{Cu}$ $(0.24)>\mathrm{Pb}(0.07)>\mathrm{Cr}$, Ni (0.03). Considering all trace metals in the mussels collected in different zones of the reservoir, the highest BASF value was found in the outlet zone (As, $\mathrm{Cd}, \mathrm{Cr}, \mathrm{Ni})$, middle zone $(\mathrm{Pb}, \mathrm{Zn})$ and inlet zone $(\mathrm{Cu})$. Among the trace metals analyzed in mussels from all sampling locations in the present study, the concentration and the BASF value varied significantly only for Cd. Generally, given the BASF values, it can be concluded that mussels had a more active role in the accumulation and binding of $\mathrm{Cd}$ and $\mathrm{Zn}$ (macroconcentrator) and lower role for As (microconcentrator). It is also notable that, at all stations, mussels showed very low $\mathrm{BASF}$ for $\mathrm{Cr}, \mathrm{Ni}, \mathrm{Pb}$, and $\mathrm{Cu}$ (deconcentrator). According to Ziyaadini et al. (2017), macroconcentrators can be particularly suitable biomonitors to determine the relationship between the concentration of a given metal in the organism and its bioavailability for bottom sediments. Therefore, A anatina can be used specifically for the measurement of cadmium in the aquatic environments.

\section{Ecotoxicity of bottom sediments}

The ecotoxicity of sediments was characterized by a low spatial variability, $\mathrm{CV}=40 \%$ (inhibition of $H$. incongruens growth) and $\mathrm{CV}=31 \%$ (inhibition of $A$. fischeri luminescence) (Fig. 2). The bottom sediments were more toxic to Heterocypris incongruens than Aliivibrio fischeri (Fig. 2). The H. incongruens growth inhibition was $11-100 \%$, with an average of $43 \%$, while the mortality rate ranged from 0 to $100 \%$, with an average of $10 \%$. The highest inhibition of crustacean growth was found in the bottom sediment sampled from the middle zone (PE 47\%) and the lowest in the inlet zone (PE 34\%). In turn, the highest mortality of $H$. incongruens was observed in the reservoir inlet zone (PE 17\%) and the lowest in the outlet zone (3\%). The mean percent inhibition of $A$. fischeri luminescence was $37 \%$ and ranged from 13 to $64 \%$. In the middle zone of the reservoir, the luminescence inhibition was the lowest (PE 34\%), while its highest value was observed in the inlet zone (PE 43\%).

Most of the tested sediment samples had low toxicity in relation to the tested organisms. For $H$. incongruens, $11 \%$ of the samples were non-toxic, $50 \%$ of the samples had low toxicity, and $39 \%$ of the samples were toxic. For A. fischeri, no toxicity was found in $7 \%$ of the samples, low toxicity in $76 \%$ of the samples and toxicity in $17 \%$ of the sediment samples.

A negative correlation was found between luminescence inhibition in A. fischeri and growth inhibition in $H$. incongruens $(\mathrm{r}=-0.30 \mathrm{p}<0.05)$, meaning differences in the sensitivity of tested organisms to toxicants present in the sediments (Fig. 2). However, the analysis indicated that the correlation between the organism was of low statistical significance and explained only $8 \%$ of the variability (Fig. 2).

\section{Correlation and PAC analyses}

The correlation between the contaminant content in the environment and in organisms is a useful method to evaluate the monitoring potential of organisms (Klink et al., 2019; Vignati et al., 2019). Numerous data indicate that there are direct relationships between the element content in the benthic organism and bottom sediments (Shirneshan et al., 2013). Table 4 shows correlations between different geochemical fractions of trace elements in the sediment and the mussel tissues. Cadmium in the tissues was strongly and very strongly significantly positively correlated with all analyzed metal fractions $(r=0.715$ F1, F4 - 0.968 F3, $p<0.05$ ). Significant, strong and very strong correlations were also determined between $\mathrm{As}, \mathrm{Zn}$ in the tissue and the content of both elements in $\mathrm{F} 1, \mathrm{~F} 4$, and the total content of $\mathrm{Zn}$ and $\mathrm{As}$ in the sediment. In addition, the study revealed negative significant correlations between the total content, F4 and $\mathrm{F} 2$ of $\mathrm{Cr}$ in the sediment and the element content in the tissue of A. anatine (Table 4). Fractions 1 and 2 of $\mathrm{Cu}$ were significantly correlated with the $\mathrm{Cu}$ content in the mussels. For Ni (F4, total) and Pb (F2, F3), there were significant negative relationships between their content in sediment and in the tissue (Table 4). The correlation analysis results confirmed our data relating to the BASF factor (Table 2). The analysis revealed high $(\mathrm{Cd}, \mathrm{Zn})$ and moderate (As) accumulation in 

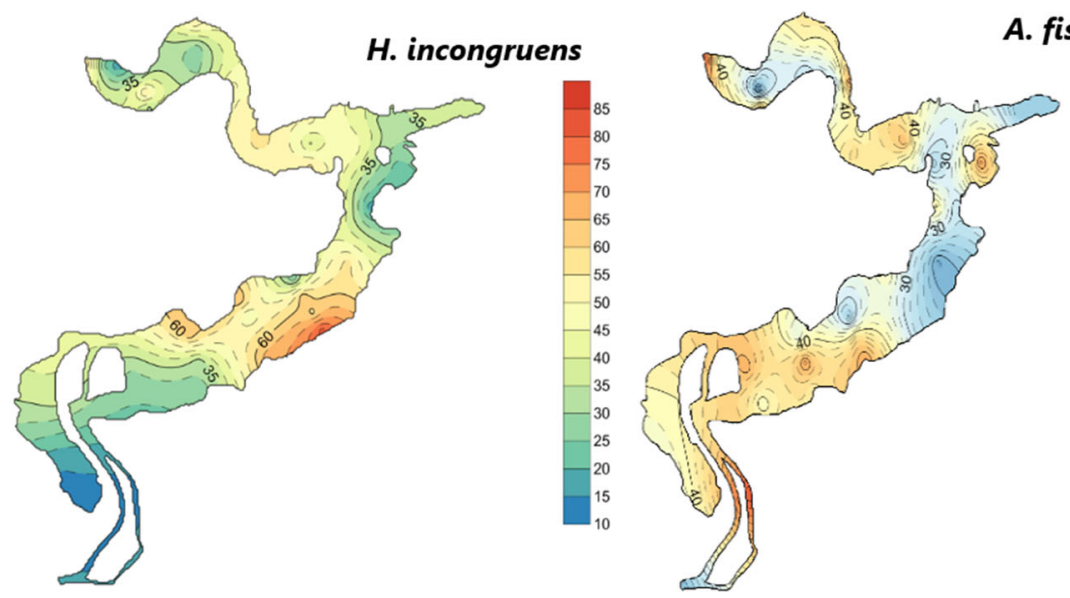

A. fischeri

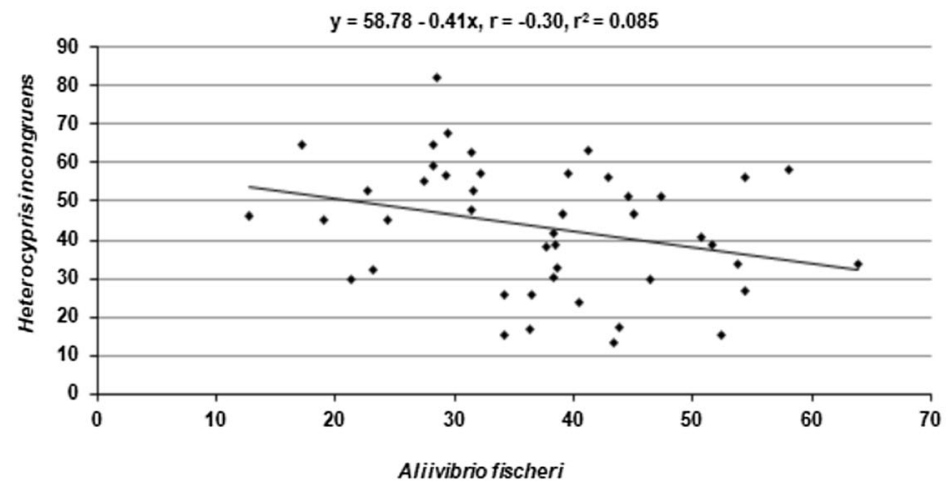

Fig. 2 Spatial distribution of luminescence inhibition (PE\%) of A. fischeri and growth inhibition (PE\%) of H. incongruens in the sediments $(n=46)$ and data pair correlations of the both response of tested organisms

Table 4 Correlation coefficients of trace element fractions in sediments and their total content in mussels

\begin{tabular}{|c|c|c|c|c|c|c|c|}
\hline \multirow[t]{2}{*}{ Sediment $n=10$} & \multicolumn{7}{|c|}{ Mussels $n=10$} \\
\hline & As & $\mathrm{Cd}$ & $\mathrm{Cr}$ & $\mathrm{Cu}$ & $\mathrm{Ni}$ & $\mathrm{Pb}$ & $\mathrm{Zn}$ \\
\hline Total & $0.996 *$ & $0.907 *$ & $-0.981 *$ & -0.225 & $-0.808 *$ & -0.583 & $0.967 *$ \\
\hline $\mathrm{F} 1$ & 0.706* & $0.715 *$ & -0.112 & $0.899 *$ & 0.597 & 0.249 & $-0.970 *$ \\
\hline $\mathrm{F} 2$ & -0.485 & $0.943 *$ & $-0.730 *$ & $0.904 *$ & -0.312 & $-0.950 *$ & $0.628 *$ \\
\hline F3 & 0.190 & 0.968* & -0.476 & 0.436 & 0.260 & $-0.996 *$ & 0.122 \\
\hline F4 & $0.961 *$ & $0.715^{*}$ & $-0.998 *$ & -0.447 & $-0.957 *$ & 0.444 & $0.954 *$ \\
\hline
\end{tabular}

*Bold values represent correlation coefficients significant at the level of $p<0.05$ : $0<\mathrm{r}<0.3$ very low correlation; $0.3 \leq \mathrm{r}<0.5$ low correlation; $0.5 \leq \mathrm{r}<0.7$ medium correlation; $0.7 \leq \mathrm{r}<0.9$ strong correlation; $0.9 \leq \mathrm{r}<1$ very strong correlation

mussel tissues, as well as the most significant positive correlations for these elements (Table 4).

The total content of trace elements in sediments had no effect on their bioavailability and mobility in water ecosystems; however, their chemical forms had ecotoxicological value (Shirneshan et al., 2013). On the other hand, the authors of the present study believe that the problem of mobility and bioavailability of trace elements is more complex and can be controlled both directly, by the total trace element content, and indirectly, related to the presence of the element in a given fraction; it can also depend on the properties of the element itself and the physicochemical factors of the medium. In our study, cadmium deserves 
particular attention, as a significant positive correlation was found between the $\mathrm{Cd}$ content (total, all fractions) in the sediments and its content in mussel tissues, which confirmed that cadmium was highly mobile in the environment shown in the fractional analysis. In turn, the total $\mathrm{Cd}$ content in the bottom sediments was generally low and the geochemical indicators showed no significant contamination of the bottom sediments with cadmium (Table 3). Therefore, when assessing the bioavailability or the degree of bioaccumulation of a given element in bottom sediments, one should take into account their total content as not to overestimate their risk to living organisms.

However, it should be noted that fractional analysis is a chemical process and knowledge of the relationship between the element fraction in the bottom sediments and element bioaccumulation in aquatic organisms provides important information on potential, rather than actual, interaction with biotic components of the aquatic environment. The correlation between the presence of metal in F1 (ion exchange fraction) and its content in living organisms gives better information on its bioavailability and can be used to predict the bioaccumulation of trace elements, as the element presence in this fraction is considered a potential hazard to aquatic organisms (Singh et al., 2005; Shrineshan et al., 2013; Baran \& Tarnawski, 2015, Klink et al., 2019). In our study, the As, Cd, Cu contents in F1 correlated significantly positively with the content of these metals in mussel tissues. There was no positive correlation between zinc F1 and its content in bivalve mussel tissues. Shirnshan et al. (2013) obtained similar results. Attention should also be paid to the positive, although insignificant, statistical correlation between the $\mathrm{Ni}$ content in the ion exchange fraction (F1) and its content in mussel tissues. For nickel, the study revealed the highest value of the potential bioaccumulation factor (PBF) estimated on the basis of fractional analysis and the lowest value of the bioaccumulation factor (BASF) calculated on the basis of the metal content in mussel tissues and bottom sediments (Table 2). It should be highlighted that both nickel and cadmium and their compounds are on the list of priority hazardous substances for water quality. What is more, they should be completely eliminated from the aquatic environment due to their highly toxic properties, bioaccumulation susceptibility and persistence (Directive 2013/39/EU of the European Parliament and of the Council of 12 August 2013). Very interesting correlation relationships were also found for the $\mathrm{Cr}$ content in individual fractions and in mussel tissues. These relationships were mostly significantly negatively correlated. As shown by geochemical indicators (Table 3) as well as our previous studies, chromium contaminates bottom sediments of the Rożnów reservoir (Baran et al., 2019b; Szara et al., 2020a). Studies by other authors have also shown that the chromium content in the bottom sediments of the Dunajec River, which feeds the two dam reservoirs: Rożnów and Czorsztyn, is also increased (Szalińska et al., 2013; Vignati et al., 2019). However, the bioaccumulation factor (BASF) calculated in this study for Cr was low, as was the potential bioaccumulation factor (PBF) (Table 2). In the study of Vignati et al. (2019), the $\mathrm{Cr}$ bioaccumulation factor value for the Chironomus sp. in the bottom sediment of the Czorsztyn reservoir (compensating reservoir for the Rożnów reservoir) was higher and ranged from 0.1 to 1.3 (Vignati et al., 2019). The higher bioaccumulation factor value may be due to the fact that Chironomus sp. are organisms that feed on the bottom sediment particles, while mussels are filter feeders and indicate the mobility of a given element from the sediment to supersedimentary water. Our study has also shown that, under the physicochemical conditions in the bottom sediments of the Rożnów reservoir, the mobility of chromium is very low despite the inflow of $\mathrm{Cr}$ with tannery wastewater (Table 2, Fig. 1). It may also indicate that the main form of chromium entering the tanning sludge is the reduced form of $\mathrm{Cr}$ (III), possibly with limited bioavailability and low ecotoxicity (Vignati et al., 2019).

Table 5 shows results of the analysis of correlation between the trace element content in individual fractions and the test organism response. The most statistically significant positive correlations were found between the content of trace elements $\mathrm{As}, \mathrm{Cr}$, $\mathrm{Ni}, \mathrm{Pb}, \mathrm{Zn}$ (total content, $\mathrm{F} 4$ ) and $H$. incongruens growth inhibition. In case of $H$. incongruens growth inhibition, significant relationships with $\mathrm{Cd}$ (F1, positive relationship) and $\mathrm{Pb}(\mathrm{F} 1$, negative relationship) were also found. The mortality of $H$. incongruens was generally negatively correlated with the content of elements in individual fractions, and statistically significant relationships were discovered only for Cr (F1, F2, F3) and Ni, Pb, Zn (F3). For $A$. fischeri, significantly positive relationships were 
Table 5 Correlation coefficients of trace element fractions and ecotoxicity of sediments

\begin{tabular}{|c|c|c|c|}
\hline $\begin{array}{l}\text { Parameters } \\
n=46\end{array}$ & $\begin{array}{l}\text { Mortality of } H \text {. } \\
\text { incongruens }\end{array}$ & $\begin{array}{l}\text { Growth } \\
\text { inhibition of } H \text {. } \\
\text { incongruens }\end{array}$ & $\begin{array}{l}\text { Inhibition of } \\
\text { luminescence } \\
\text { A. fischeri }\end{array}$ \\
\hline Total As & -0.184 & 0.333 & 0.188 \\
\hline Total Cd & -0.093 & 0.179 & 0.251 \\
\hline Total $\mathrm{Cr}$ & -0.106 & 0.345 & 0.112 \\
\hline Total $\mathrm{Cu}$ & -0.005 & 0.189 & -0.001 \\
\hline Total Ni & -0.041 & 0.323 & 0.073 \\
\hline Total Pb & -0.099 & 0.368 & 0.111 \\
\hline Total Zn & 0.111 & 0.471 & -0.031 \\
\hline F1 As & -0.170 & 0.082 & 0.162 \\
\hline $\mathrm{F} 1 \mathrm{Cd}$ & 0.061 & 0.311 & -0.198 \\
\hline $\mathrm{F} 1 \mathrm{Cr}$ & -0.311 & -0.038 & -0.039 \\
\hline $\mathrm{F} 1 \mathrm{Cu}$ & -0.265 & 0.016 & 0.296 \\
\hline $\mathrm{F} 1 \mathrm{Ni}$ & 0.142 & 0.138 & $-\mathbf{0 . 3 7 3}$ \\
\hline $\mathrm{F} 1 \mathrm{~Pb}$ & -0.113 & -0.442 & 0.116 \\
\hline $\mathrm{F} 1 \mathrm{Zn}$ & 0.125 & 0.146 & 0.060 \\
\hline F2 As & 0.004 & 0.218 & 0.192 \\
\hline $\mathrm{F} 2 \mathrm{Cd}$ & -0.086 & 0.061 & 0.265 \\
\hline $\mathrm{F} 2 \mathrm{Cr}$ & $-\mathbf{0 . 3 5 2}$ & -0.018 & 0.285 \\
\hline $\mathrm{F} 2 \mathrm{Cu}$ & -0.235 & -0.127 & 0.343 \\
\hline F2 Ni & -0.244 & 0.090 & 0.260 \\
\hline $\mathrm{F} 2 \mathrm{~Pb}$ & -0.220 & 0.123 & 0.295 \\
\hline $\mathrm{F} 2 \mathrm{Zn}$ & -0.085 & 0.244 & 0.190 \\
\hline F3 As & -0.090 & -0.035 & 0.133 \\
\hline F3 Cd & -0.162 & -0.019 & 0.344 \\
\hline $\mathrm{F} 3 \mathrm{Cr}$ & $-\mathbf{0 . 3 7 9}$ & -0.024 & 0.323 \\
\hline $\mathrm{F} 3 \mathrm{Cu}$ & -0.148 & 0.041 & 0.145 \\
\hline F3 Ni & -0.465 & -0.287 & 0.391 \\
\hline $\mathrm{F} 3 \mathrm{~Pb}$ & -0.346 & 0.005 & 0.372 \\
\hline F3 Zn & -0.305 & 0.005 & 0.216 \\
\hline F4 As & -0.170 & 0.355 & 0.158 \\
\hline $\mathrm{F} 4 \mathrm{Cr}$ & -0.067 & 0.370 & 0.079 \\
\hline $\mathrm{F} 4 \mathrm{Cu}$ & 0.055 & 0.178 & -0.063 \\
\hline F4 Ni & 0.272 & 0.482 & -0.167 \\
\hline $\mathrm{F} 4 \mathrm{~Pb}$ & 0.245 & 0.462 & -0.281 \\
\hline $\mathrm{F} 4 \mathrm{Zn}$ & 0.222 & 0.443 & -0.164 \\
\hline
\end{tabular}

*Bold values represent correlation coefficients significant at the level of $p<0.05$ : $0<\mathrm{r}<0.3$ very low correlation; $0.3 \leq \mathrm{r}<0.5$ low correlation; $0.5 \leq \mathrm{r}<0.7$ medium correlation; $0.7 \leq \mathrm{r}<0.9$ strong correlation; $0.9 \leq \mathrm{r}<1$ very strong correlation

observed with metals present in $\mathrm{F} 1(\mathrm{Cu}), \mathrm{F} 2(\mathrm{Cu}, \mathrm{Pb})$ and $\mathrm{F} 3(\mathrm{Cd}, \mathrm{Cr}, \mathrm{Ni}, \mathrm{Pb})$ as well as negative relationships with $\mathrm{F} 1(\mathrm{~Pb})$. It should be noted that, for all relevant relationships, the obtained Person's correlation coefficients were low or very low (Table 5). This can be explained by several factors. First of all, as stated in Sect. 4, most sediment samples showed relatively low toxicity to the test organisms and, as stated in Sect. 3.1, they were barely mobile. Secondly, the lack of significant relationships between the trace element content in individual fractions and the response of test organisms suggests their relatively low mobility and bioavailability (except for $\mathrm{Cd}$ ). Additionally, other contaminants such as ammonia, pesticide residues, PAHs, biogens or dioxins may be present in the Rożnów reservoir sediments, having effect on the trace element toxicity (Baran et al., 2019b; Szara et al., 2020a). Furthermore, the interactions between different substances present in the sediment may cause synergistic or antagonistic effects that are difficult to predict and analyze (Apitz, 2011; Baran et al., 2016; de Castro-Catala et al., 2016; Hise et al., 2020). The correlation analysis showed that $A$. fischeri was a less sensitive organism than $H$. incongruens. What is more, the crustacean growth inhibition was associated with the content of trace element in stable forms-while the bacteria luminescence inhibition-with potentially mobile metal fractions (F2 and F3). The differences in the sensitivity of the tested organisms concern not only the species, trophic group or contamination type, but also the way they are exposed to toxic substances. In the Ostracodtoxkit test, crustaceans were exposed to both soluble contaminants and contaminants absorbed on sediment particles, while exposure of bacteria (Microtox) was limited to dissolved and thus more mobile substances. It is worth mentioning here that potentially mobile element fractions F2 and F3 positively correlated with inhibition of bacterial luminescence (Table 5). Our previous studies also showed a lower toxicity of the Rożnów reservoir bottom sediments to the test plants (Lepidium sativum, Sinapis alba, Sorghum saccharatum) than to Thamnocephalus platyurus (Szara et al., 2020a). On the other hand, Baran et al. (2016) evaluated the sensitivity of the performed tests and obtained a higher number of toxic responses for $A$. fischeri than for $H$. incongruens in sediments whose organic matter content was high.

Numerous factors control the chemical fractions of trace elements in bottom sediments (Baran \& Tarnawski, 2015; Martinez-Santos et al., 2015; Aguilar Hinojosa et al., 2016; Baran et al., 2019a; Klink et al., 
2019). In our previous study, the analysis involved the $\mathrm{pH}$, particle size, organic carbon and Fe contents (Szara et al., 2020a). The PCA extracted four positive correlations responsible for $72.55 \%$ of the dataset total variance (Table 6). The PC1, explaining $36.85 \%$ of the total variance, had strongly positive loadings $(>0.70)$ on silt, $\mathrm{Fe}$, and stable forms of trace elements (total content and $\mathrm{F} 4$ of $\mathrm{As}, \mathrm{Cd}, \mathrm{Cr}, \mathrm{Ni}, \mathrm{Pb}, \mathrm{Zn}$ ) and negative loadings on sand. The second factor (PC2) explained $20.61 \%$ of the total variance and was dominated by clay and the trace element content in $\mathrm{F} 2(\mathrm{Cr}, \mathrm{Ni}, \mathrm{Pb})$ and F3 (As, Cr, Ni, Pb, Zn). The third factor was responsible for $9.05 \%$ of the total variance and was highly loaded on the content of Cd (total, F2, F3), As, $\mathrm{Zn}$ and $\mathrm{Pb}(\mathrm{F} 1)$ and $\mathrm{Cu}(\mathrm{F} 2)$ (Table 6). The fourth factor (PC4), i.e., only 6.04\% of variance, displayed high loading values of $\mathrm{F} 1 \mathrm{Cd}, \mathrm{Cr}$, and $\mathrm{Ni}$. It is believed that the total elemental content in sediments does not provide reliable information on anthropogenic sources, as it is strongly related to the properties of the bottom sediments (Klink et al., 2019). The results of the PCA partially confirmed the dependence indicated above. In our study, PC1 represented natural factors and sources determining the trace element content in the Rożnów reservoir bottom sediments. $\mathrm{PC} 1$ indicated that the silt fraction, which is dominant for the bottom sediment, has a significant effect on the total (As, Cd, Ni, Pb, Zn, Cr) and F4 (As, Cr, Ni, Pb, $\mathrm{Zn}$ ) content of trace elements. A significantly positive correlation (PC1) was also demonstrated between the content of $\mathrm{Fe}$ and the content of most trace elements (total content, F4), which may also suggest that their sources were natural. PCA results also indicated significantly positive correlations between trace elements (total content, F4) in the Rożnów reservoir bottom sediments, which was related to similar sources and distribution routes, rather of natural origin. Hu et al. (2013) and Baran et al. (2019b) obtained similar results. The study revealed an insignificant relationship between the total element contents and fractions and the TOC contents in the sediments. As demonstrated in our previous studies, the reservoir rheolimnetic nature and the relatively low TOC content suggest that TOC is not the main factor affecting the content of trace elements and their distribution in individual fractions in the studied bottom sediments (Baran et al., 2019b). No significant effect of $\mathrm{pH}$ on the content and distribution of trace elements in bottom sediments was determined in the present study. The mobility of trace elements in the Rożnów reservoir sediments may be limited due to the neutral and alkaline sediment $\mathrm{pH}$, as evidenced by the low element contents in the F1 and F2 fractions. The characteristics of trace elements bound to $\mathrm{PC} 2$ and PC3 indicate mixed (natural and anthropogenic) sources/control factors in the Rożnów reservoir sediments. As stated in Sect. 3.1, elements present in the F2 and F3 fractions are potentially mobile and their distribution may be related both to emissions from earlier anthropogenic sources and natural factors of the aquatic environment. We observed (PC2) a significant effect of the clay fraction on the element presence in the $\mathrm{F} 2$ and $\mathrm{F} 3$ fractions $(\mathrm{Cr}, \mathrm{Ni}, \mathrm{Pb}, \mathrm{Ni})$, and for other elements, this effect was also positive but statistically insignificant. At this point, it is worth mentioning that the Rożnów reservoir is the fastest silting dam reservoir in Poland (Szarek-Gwiazda, 2014; Baran et al., 2019b; Szara et al., 2020a, 2020b). The average amount of retained mineral material ranges between 470 thousand $\mathrm{m}^{3} /$ year and 2150 thousand $\mathrm{m}^{3}$ / year and is the highest in Poland (Baran et al., 2019a). Silting is responsible for the inflow of small fractions whose origin is both natural and anthropogenic. The fine fraction, especially the clay fraction, has a large sorption area compared to trace elements. Geological structure of the catchment area, frequent floods, surface waters from cropland is the main factors affecting silting. Additionally, the main anthropogenic source here is the inflow of municipal sewage directly into the reservoir (Szara et al., 2020a; Szarek-Gwiazda, 2014). Iron and manganese geometry and thus the redox potential are the natural processes that significantly influence the behavior, form and the further activity of trace elements in the aquatic environment (Wang et al., 2012; Zhou, 2020). The results of a low redox potential are the reduction of sulfates as well as the formation of insoluble sulfides. Under reducing conditions, the formation of insoluble sulfides causes the immobilization and binding of some metals, such as copper, zinc, lead, cadmium, nickel, into immobile sulfides inaccessible to living organisms. On the other hand, in the case of manganese and iron, the lower the redox potential, the stronger the reduction processes and the hydrated manganese (IV) and iron (III) oxides in the sediment are reduced. Under anaerobic (reducible) conditions, trace elements absorbed on the developed surface of the precipitating hydrated iron and manganese oxides 
Table 6 PCA applied to the results of trace element fractions and chemical, physical and ecotoxicological properties of sediments

\begin{tabular}{|c|c|c|c|c|}
\hline Parameters & PC1 & PC2 & PC3 & PC4 \\
\hline Sand & -0.918 & -0.211 & -0.008 & -0.059 \\
\hline Silt & 0.790 & -0.190 & -0.137 & 0.018 \\
\hline Clay & 0.374 & 0.728 & 0.253 & 0.081 \\
\hline TOC & 0.238 & -0.489 & -0.062 & -0.261 \\
\hline $\mathrm{pH}$ & 0.098 & 0.010 & -0.409 & 0.073 \\
\hline $\mathrm{Fe}$ & 0.731 & 0.315 & 0.076 & -0.038 \\
\hline Total As & 0.803 & 0.468 & 0.135 & -0.027 \\
\hline Total Cd & 0.300 & 0.259 & 0.861 & -0.117 \\
\hline Total Cr & 0.870 & 0.445 & 0.105 & 0.105 \\
\hline Total $\mathrm{Cu}$ & 0.510 & 0.039 & 0.048 & 0.119 \\
\hline Total Ni & 0.871 & 0.360 & 0.148 & 0.159 \\
\hline Total $\mathrm{Pb}$ & 0.866 & 0.432 & 0.126 & 0.003 \\
\hline Total Zn & 0.960 & 0.151 & 0.047 & -0.015 \\
\hline F1 As & 0.363 & -0.031 & 0.793 & 0.056 \\
\hline $\mathrm{F} 1 \mathrm{Cd}$ & 0.021 & 0.484 & 0.083 & 0.778 \\
\hline $\mathrm{F} 1 \mathrm{Cr}$ & -0.132 & 0.358 & -0.056 & 0.803 \\
\hline $\mathrm{F} 1 \mathrm{Cu}$ & 0.162 & -0.278 & 0.500 & 0.489 \\
\hline $\mathrm{F} 1 \mathrm{Ni}$ & -0.597 & 0.154 & -0.286 & 0.797 \\
\hline $\mathrm{F} 1 \mathrm{~Pb}$ & 0.014 & -0.275 & -0.094 & 0.062 \\
\hline $\mathrm{F} 1 \mathrm{Zn}$ & 0.048 & 0.119 & 0.796 & 0.123 \\
\hline $\mathrm{F} 2 \mathrm{As}$ & 0.356 & 0.195 & 0.266 & 0.163 \\
\hline $\mathrm{F} 2 \mathrm{Cd}$ & 0.070 & 0.120 & 0.959 & -0.158 \\
\hline $\mathrm{F} 2 \mathrm{Cr}$ & 0.240 & 0.788 & 0.369 & 0.200 \\
\hline $\mathrm{F} 2 \mathrm{Cu}$ & -0.083 & 0.433 & 0.855 & -0.032 \\
\hline $\mathrm{F} 2 \mathrm{Ni}$ & 0.502 & 0.707 & 0.265 & 0.200 \\
\hline $\mathrm{F} 2 \mathrm{~Pb}$ & 0.398 & 0.650 & 0.572 & 0.144 \\
\hline $\mathrm{F} 2 \mathrm{Zn}$ & 0.549 & 0.462 & 0.265 & 0.065 \\
\hline F3 As & -0.007 & 0.698 & 0.026 & -0.110 \\
\hline $\mathrm{F} 3 \mathrm{Cd}$ & 0.014 & 0.356 & 0.894 & -0.106 \\
\hline $\mathrm{F} 3 \mathrm{Cr}$ & 0.149 & 0.900 & 0.249 & 0.020 \\
\hline $\mathrm{F} 3 \mathrm{Cu}$ & 0.178 & 0.401 & 0.008 & -0.207 \\
\hline F3 Ni & -0.177 & 0.934 & 0.191 & 0.066 \\
\hline $\mathrm{F} 3 \mathrm{~Pb}$ & 0.261 & 0.906 & 0.107 & -0.072 \\
\hline F3 Zn & 0.167 & 0.890 & 0.062 & -0.008 \\
\hline F4 As & 0.852 & 0.347 & 0.126 & 0.042 \\
\hline $\mathrm{F} 4 \mathrm{Cr}$ & 0.909 & 0.366 & 0.074 & 0.086 \\
\hline $\mathrm{F} 4 \mathrm{Cu}$ & 0.450 & -0.104 & 0.000 & 0.173 \\
\hline F4 Ni & 0.909 & -0.286 & 0.012 & -0.008 \\
\hline $\mathrm{F} 4 \mathrm{~Pb}$ & 0.823 & -0.424 & -0.187 & 0.005 \\
\hline $\mathrm{F} 4 \mathrm{Zn}$ & 0.913 & -0.173 & -0.245 & -0.057 \\
\hline Mortality $H$. incongruens & 0.173 & -0.512 & -0.032 & -0.078 \\
\hline Growth inhibition $H$. incongruens & 0.530 & -0.236 & 0.105 & 0.082 \\
\hline Luminescence inhibition A. fischeri & -0.090 & 0.397 & 0.238 & -0.274 \\
\hline Total variance $(\%)$ & 36.847 & 20.610 & 9.054 & 6.040 \\
\hline Cumulative (\%) & 36.847 & 57.457 & 66.513 & 72.553 \\
\hline
\end{tabular}

Loadings $>0.6$ are shown in bold; $n=46$ 
(F2) may be released from the sediment into the water. The PC2 showed that the content of elements in the F2 fraction positively correlated with the iron content; however, these correlations were statistically insignificant.

The characteristics of trace elements bound to PC4 indicate their anthropogenic sources $(\mathrm{Cd}, \mathrm{Ni}, \mathrm{Cr})$ in the Rożnów reservoir bottom sediments. These results are consistent with our previous study, since nickel, chromium and cadmium pose a significant risk in the Rożnów reservoir bottom sediments (Baran et al., 2019b; Szara et al., 2020a). All these elements are deposited in the reservoir mainly with household and industrial wastewater (Vignati et al., 2019). Nickel is widely used in industry, and its high concentrations can be found in sediments and soils in urban areas. Therefore, high nickel content in sediments is a good indicator of recent anthropogenic contamination (de Castro-Catala et al., 2016). As mentioned above, the presence of chromium in the Rożnów reservoir bottom sediments may result from a large number of tanneries operating in the Dunajec river catchment area, having permits to discharge tanning waste water and an unknown number of plants not entered in the register (Vignati et al., 2019). The PCA showed that cadmium behaved differently from other elements determined in the bottom sediments. This relationship was also demonstrated in our previous study on the metal content of core bottom sediment samples from the Rożnów reservoir (Baran et al., 2019b), confirming the anthropogenic sources of the metal. In addition, the significant share of the first three fractions in the $\mathrm{Cd}$ bond (exceeding $90 \%$ in the present study) and the high bioaccumulation factor (BAFS) value are compatible with the results obtained in various studies on the sediments of many lakes and rivers around the world. They also prove the relatively high mobility of the element in bottom sediments (Njeng et al., 2009; Sundaray et al., 2011; Kulbat \& Sokołowska, 2019).

\section{Conclusions}

1. Our study revealed three elements deserving attention in the Rożnów reservoir sediments: cadmium, nickel and chromium. However, cadmium proved to be the most mobile and bioavailable, although the total cadmium content and geochemical indicators did not reveal any risk to organisms. Geochemical indicators showed that the bottom sediments are contaminated with nickel and chromium, but both elements had a low bioaccumulation factor (BASF). Fractional analysis also revealed relatively low mobility of $\mathrm{Cr}$ and $\mathrm{Ni}$ and a higher potential risk of bioavailability for nickel.

2. Research on the mobility, bioavailability and bioaccumulation of trace elements in bottom sediments is very difficult and requires data on the physicochemical properties of the sediments, as well as the geochemical, ecotoxicological, biological and environmental properties relating to the contamination sources. Only understanding the above factors will provide comprehensive and real, rather than potential, information on the mean effects associated with further activity of trace elements in aquatic systems.

3. Both biotesting and chemical analysis evaluate sediments under standardized conditions which do not necessarily correspond to in situ conditions. Therefore, both can reveal a potential risk to aquatic organisms. However, ecotoxicological tests are more effective in detecting the effects of mixtures of contaminants and substances that are not tested. For a real assessment of the ecological risks associated with trace elements, it is necessary to use bioindicators taken from the environment and exposed to trace elements in situ.

Acknowledgements The study was financed by Grant No. 2016/21/B/ST10/02127: "Assessment of the bottom sediment organic matter on bioavailability and toxicity of chemical compounds" provided by the National Science Centre, Poland, and by "Innovative program of strategic development of the University" co-financed by the European Social Fund, contract no. POWR.03.05.00-00-Z020/18. We are grateful to Dr. Marek Tarnawski (University of Agriculture in Kraków) for sampling of samples (bottom sediments and mussels).

\section{Declarations}

Human and animals rights No approval of research ethics committees was required to accomplish the goals of this study.

Informed consent Informed consent was obtained from all individual participants included in the study.

Open Access This article is licensed under a Creative Commons Attribution 4.0 International License, which permits use, sharing, adaptation, distribution and reproduction in any 
medium or format, as long as you give appropriate credit to the original author(s) and the source, provide a link to the Creative Commons licence, and indicate if changes were made. The images or other third party material in this article are included in the article's Creative Commons licence, unless indicated otherwise in a credit line to the material. If material is not included in the article's Creative Commons licence and your intended use is not permitted by statutory regulation or exceeds the permitted use, you will need to obtain permission directly from the copyright holder. To view a copy of this licence, visit http://creativecommons.org/licenses/by/4.0/.

\section{References}

Aguilar-Hinojosa, Y., Meza-Figueroa, D., Villalba-Atondo, A. I., Encinas-Romero, M. A., Valenzuela-García, J. L., \& Gómez-Álvarez, A. (2016). Mobility and bioavailability of metals in stream sediments impacted by mining activities: the Jaralito and the Mexicana in Sonora, Mexico. Water, Air and Soil Pollution, 227, 345

Al-Mur, B. (2020). Geochemical fractionation of heavy metals in sediments of the Red Sea, Saudi Arabia. Oceanologia, $62,31-44$

Apitz, S. (2011). Sustainable sediment management? Integrated Environmental Assessment and Management, 7(4), 691-693

Ashokkumar, S., Mayavu, P., Sampathkumar, P., Manivasagam, P., Rajaram, G., Marinebiology, C. A. S., \& Nadu, T. (2009). Seasonal distribution of heavy metals in the Mullipallam creek of Muthupettai mangroves (southeast coast of India). American Scientific Research Journal, 4, 308-312

Bacon, J. R., \& Davidson, C. M. (2008). Is there a future for Sequential chemical extraction? The Analyst, 133, 25-46

Baran, A., Mierzwa-Hersztek, M., Gondek, K., Tarnawski, M., Szara, M., Gorczyca, O., \& Koniarz, T. (2019a). The influence of the quantity and quality of sediment organic matter on the potential mobility and toxicity of trace elements in bottom sediment. Environmental Geochemical and Health, 41, 2893-2910

Baran, A., Tarnawski, M., Koniarz, T., \& Szara, M. (2019b). Content of nutrients, trace elements, and ecotoxicity of sediment cores from Rożnów reservoir (Southern Poland). Environmental Geochemical and Health, 41, 2929-2948

Baran, A., Tarnawski, M., \& Koniarz, T. (2016). Spatial distribution of trace elements and ecotoxicity of bottom sediments in Rybnik reservoir. Silesian-Poland. Environmental Science and Pollution Research, 23(17), 17255-17268

Baran, A., \& Tarnawski, M. (2015). Assessment of heavy metals mobility and toxicity in contaminated sediments by sequential extraction and a battery of bioassays. Ecotoxicology, 24(6), 1279-1293

Baran, A., \& Tarnawski, M. (2013). Phytotoxkit/Phytotestkit and Microtox ${ }^{\circledR}$ as tools for toxicity assessment of sediments. Ecotoxicology and Environmental Safety, 98, 19-27

BCR Information Reference Materials (2001). The certification of the extractable contents (mass fractions) of $\mathrm{Cd}, \mathrm{Cr}, \mathrm{Cu}$,
$\mathrm{Ni}, \mathrm{Pb}$ and $\mathrm{Zn}$ in freshwater sediment following a sequential extraction procedure, BCR-701. Community Research, Competitive and Sustainable Growth.

Bielicka-Giełdoń, A., Ryłko, E., \& Żamoć, K. (2013). Distribution, bioavailability and fractionation of metallic elements in allotment garden soils using the BCR sequential extraction procedure. Polish Journal of Environmental Studies, 22(4), 1013-1021

Birch, G. (2017). Determination of sediment metal background concentrations and enrichment in marine environments-a critical review. Science of The Total Environment, 580, 813-831

Birch, G., \& Apostolatos, C. (2013). Use of sedimentary metals to predict metal concentrations in black mussel (Mytilus galloprovincialis) tissue and risk to human health (Sydney estuary, Australia). Environmental Science and Pollution Research, 20, 5481-5549

Bojakowska, I. (2001). Criteria for evaluation of water sediments pollution. Polish Geological Review, 49(3), 213-219

Burgos, M., \& Rainbow, P. (2001). Availability of cadmium and zinc from sewage sludge to the flounder, Platichthysflesus, via a marine food chain. Marine Environmental Research, $51,417-439$

Cooman, W., Blaise, C., Janssen, L., Detemmerman, R., \& Persoone, G. (2015). History and sensitivity comparison of two standard whole-sediment toxicity tests with crustaceans: the amphipod Hyalella azteca and the ostracod Heterocypris incongruens microbiotest. Knowledge and Management of Aquatic Ecosystems, 416, 15

Copaja, S. V., Molina, X., \& Tessada, R. (2014). Determination of heavy metals in Choapa river sediments using BCR sequential extraction procedure. Journal of the Chilean Chemical Society, 59, 2353-2358

de Castro-Català, N., Kuzmanovic, M., Roig, N., et al. (2016). Ecotoxicity of sediments in rivers: invertebrate community, toxicity bioassays and toxic unit approach as complementary assessment tools. Science of The Total Environment, 540, 297-306

Directive 2013/39/EU of the European Parliament and of the Council of 12 August 2013

Gleyzes, C., Tellier, S., \& Astruc, M. (2002). Fractionation studies of trace elements in contaminated soils and sediments: a review of sequential extraction procedures. Trends in Analytical Chemistry, 21, 451-467

Håkanson, L. (1980). An ecological risk index for aquatic pollution control. A sedimentological approach. Water Research, 14, 975-1001

Hise, S., Babut, M., Casado, C., et al. (2020). Ecotoxicological testing of sediments and dredged material: An overlooked opportunity? Journal of Soils and Sediments, 20, 4218-4228. https://doi.org/10.1007/s11368-020-02798-7

Honda, M., \& Suzuki, N. (2020). Toxicities of polycyclic aromatic hydrocarbons for aquatic animals. International Journal of Environmental Research and Public Health, 17, 1363

Horsfall, M., \& Spiff, A. (2002). Distribution and partitioning of trace metals in sediments of the lower reaches of the New Calabar River, Port Harcourt, Nigeria. Environmental Monitoring and Assessment, 78, 309-326 
Klink, A., Dambiec, M., \& Polechońska, L. (2019). Trace metal speciation in sediments and bioaccumulation in Phragmitesaustralis as tools in environmental pollution monitoring. International Journal of Environmental Science and Technology, 16, 7611-7622

Kuczyńska, A., Wolska, L., \& Namieśnik, J. (2005). Application of biotests in environmental research. Critical Reviews in Analytical Chemistry, 35(2), 135-154

Kulbat, E., \& Sokołowska, A. (2019). Methods of assessment of metal contamination in bottom sediments (Case Study: Straszyn Lake, Poland). Archives of Environmental Contamination and Toxicology, 77, 605-618

Lyubenova, M., Boteva, S. (2016). Biotests in Ecotoxicology: Current practice and problems in toxicology - New Aspects to This Scientific Conundrum doi: https://doi.org/10.5772/ 64776

Martınez-Santos, M., Probst, A., Garcı'a-Garcı'a, J., \& RuizRomera, E. (2015). Influence of anthropogenic inputs and a high-magnitude flood event on metal contamination pattern in surface bottom sediments from the Deba River urban catchment. The Science of Total Environment, 514, $10-25$

Microbics Corporation. (1992). Microtox manual toxicity testing handbook. Carlsbad, CA, USA

Morillo, J., Rojas, R., \& Usero, J. (2008). Fractionation of metals and As in sediments from a biosphere reserve (Odiel salt marshes) affected by acidic mine drainage. Environmental Monitoring and Assessment, 139, 329-337

Nieto, J. M., Sarmiento, A. M., Olías, M., Canovas, C. R., Riba, I., Kalman, J., \& Delvalls, T. A. (2007). Acid mine drainage pollution in the Tinto and Odiel rivers (Iberian pyrite belt, SW Spain) and bioavailability of the transported metals to the Huelva estuary. Environment International, $33,445-455$

Ostracodtoxkit, F. (2001). Direct contact toxicity test for freshwater sediments. (p. 35). MicroBioTestInc.

Persoone, G., Marsalek, B., Blinova, I., et al. (2003). A practical and userfriendly toxicity classification system with microbiotests for natural waters and wastewaters. Environmental Toxicology, 18(6), 395-402

Rosado, D., Morillo, J., \& Usero, J. (2016). Ability of 3 extraction methods (BCR, Tessier and protease $\mathrm{K}$ ) to estimate bioavailable metals in sediments from Huelva estuary (Southwestern Spain). Marine Pollution Bulletin, 102, 65-71

Sarkar, S. K., Favas, P. J. C., Rakshit, D., \& Satpathy, K. K. (2014). Geochemical speciation and risk assessment of heavy metals in soils and sediments. Environmental Risk Assessment of Soil Contamination. https://doi.org/10.5772/ 57295

Shirneshan, G., Alireza, R., \& B., Seyed, J. S., Samar, M. . (2013). Significant correlation of $\mathrm{Cd}, \mathrm{Cu}, \mathrm{Pb}$ and $\mathrm{Zn}$ in sediments and oysters (Saccostreacucullata) collected from Qeshm Island, Persian Gulf. Iran. Chemical Speciation \& Bioavailability, 25(4), 291-302

Singh, K. P., Malik, A., Sinha, S., Singh, V. K., \& Murthy, R. C. (2005). Estimation of source of heavy metal contamination in sediments of Gomti River (India) using Principal Component Analysis. Water, Air, and Soil Pollution, 166, 321-341
Szara, M., Baran, A., Klimkowicz-Pawlas, A., \& Tarnawski, M. (2020a). Ecotoxicological characteristics and ecological risk assessment of trace elements in the bottom sediments of the Rożnów reservoir (Poland). Ecotoxicology, 29(1), $45-57$

Szara, M., Baran, A., Klimkowicz-Pawlas, A., \& Tarnawski, M. (2020b). Ecotoxicological and chemical properties of the Rożnów reservoir bottom sediment amended with various waste materials. Journal of Environmental Management, 273, 111176

Szarek-Gwiazda, E. (2014). Potential effect of $\mathrm{pH}$ on the leaching of heavy metals from sediments of the Carpathian dam reservoirs. Geology, Geophysics \& Environment, 40(4), 349-358

Szefer, P., Ali, A. A., Ba-Haroon, A. A., Rajeh, A. A., Gełdon, J., \& Nabrzyski, M. (1999). Distribution and relationships of selected trace metals in molluscs and associated sediments from the Gulf of Aden, Yemen. Environmental Pollution, 106, 299-314

Tarnawski, M., Baran, A., Koniarz, T., Wyrębek, M., Grela, J., Piszczek, M., \& Korolu, A. (2017). The possibilities of the environmental use of bottom sediments from the silted inlet zone of the Rożnów reservoir. Geology Geophysics \& Environment, 43, 335-344

Terekhova, A., Wdhia, K., Fedoseeva, E., \& Uchano, P. (2018). Bioassay standardization issues in freshwater ecosystem assessment: test cultures and test conditions. Knowledge and management of aquatic ecosystems, 419, 32

Tytła, M., \& Kostecki, M. (2019). Ecological risk assessment of metals and metalloid in bottom sediments of water reservoir located in the key anthropogenic "hot spot" area (Poland). Environmental Earth Sciences, 78, 179

Vignati, D. A. L., Ferrari, B. J. D., Roulier, J. L., Coquery, M., Szalinska, E., Bobrowski, A., \& Dominik, J. (2019). Chromium bioavailability in aquatic systems impacted by tannery wastewaters. Part 1: understanding chromium accumulation by indigenous chironomids. The Science of the Total Environment, 653, 401-408

Wadhia, K., \& Thompson, K. C. (2007). Low-cost ecotoxicity testing of environmental samples using microbiotests for potential implementation of the Water Framework Directive. Trends in Analytical Chemistry, 26(4/2), 300-307

Zhangb, W., Wang, X., \& Liu, B. (2019). An Ex-Situ Immobilization Experiment with $\mathrm{Zn}, \mathrm{Pb}$ and $\mathrm{Cu}$ in Dredged Marine Sediments from Bohai Bay China. Journal of Marine Science and Engineering, 7, 394. https://doi.org/ 10.3390/jmse7110394

Zhou, C., Gaulier, C., Luo, M., Guo, W., Baeyens, W., \& Gao, Y. (2020). Fine scale measurements in Belgian coastal sediments reveal different mobilization mechanisms for cationic trace metals and oxyanions. Environment International., 145, 106140

Ziyaadini, M., Yousefiyanpour, Z., Ghasemzadeh, J., \& Zahedi, M. M. (2017). Biota-sediment accumulation factor and concentration of heavy metals $(\mathrm{Hg}, \mathrm{Cd}, \mathrm{As}, \mathrm{Ni}, \mathrm{Pb}$ and $\mathrm{Cu}$ ) in sediments and tissues of Chitonlamyi (Mollusca: Polyplacophora: Chitonidae) in Chabahar Bay. Iran. Iranian Journal of Fisheries Sciences, 16(4), 1123-1134 
Zoumis, T., Schmidt, A., Grigorova, L., \& Calmano, W. (2001). Contaminants in sediments: Remobilisation and demobilisation. The Science of the Total Environment, 266, 195-202
Publisher's Note Springer Nature remains neutral with regard to jurisdictional claims in published maps and institutional affiliations. 